\title{
Sweet potato as a ruminant feed: Performance of sheep fed mixtures of the forage and root.
}

\section{O.A. Olorunnisomo}

Department of Animal Production and Health Sciences, University of Ado-Ekiti, PMB 5363, Ado-Ekiti, Nigeria.

\begin{abstract}
Scarcity of quality forage during the dry season poses a serious problem to ruminant production in sonthwest Nigeria. Dried sweet potato (SP) vine and root have the potential to bridge the gap in feed supply for ruminants during this period. In a feeding trial, fifteen male West African dwarf (WAD) sheep were used to estimate the nutritive value of $S P$ forage and root as a basal feed for ruminants during the dry season. Experimental diets consisted of SP forage and root in the following proportions, 0:100, 25:75, 50:50, 75:25, and 100:0 (forage. root). In the first part of the trial, growing WAD sheep were fed experimental diets for twenty weeks. Dry matter (DM) intake and growth rate of the animals were measured. In the second part, digestibility and nitrogen balance of sheep fed the experimental diets were measured. Intake, growth rate, digestibility and nitrogen retention improved significantly $(P<0.05)$ when $S P$ forage and root were mixed in the diet. The DM intake ranged from 1.8 to $4.9 \%$ body weight; growth rate, $\quad-34.1$ to $86.43 \mathrm{~g} /$ day; DM digestibility, 64.6 to $70.4 \%$; and nitrogen retained, 29.5 to $51.0 \%$. Performance, digestibility and nitrogen utilization of WAD sheep was highest when SP forage and root formed equal proportions (50:50) in the diet. Mixing SP forage and root in the diet proved beneficial to growing sheep and equal proportions of the forage and root in the diet appear to be the most appropriate combination.
\end{abstract}

Keywords: Sweet potato, Sheep, Intake, Growth, Digestibility, Nitrogen Balance

\section{Introduction}

Inadequate supply of quality forage on a year round basis is a major problem to the productivity of ruminants in the southwest of Nigeria. Yield and quality of forage from perennial tropical grasses decline rapidly toward the dry season, leading to a shortage in supply of quality feed during this period. Under improved cultivation, sweet potato is capable of producing a very high dry matter yield per unit area of land. Yields of 22 $\mathrm{t} / \mathrm{ha}$ of forage and $11 \mathrm{t} / \mathrm{ha}$ of roots have been reported (Rashid et al., 2000; Moat and Dryden, 1993). The vine is rich in protein while the root is rich in energy (An et al., 2003). Digestibility of sweet potato forage and roots for pigs has been reported by Giang et al. (2004) to be very high. In vitro digestibility of sweet potato forage and roots has also been reported by Backer et al. (1980) to be high. There is however, a paucity of information on the in vivo digestibility of this fodder crop for ruminants.

The chemical composition and high yield of sweet potato makes it a crop of great potential for feeding ruminants during periods of feed scarcity in Nigeria. Sweet potato vines have been fed to ruminants as forage while the root has formed part of the concentrate diet (Lam and Ledin, 2004; Tewe et al., 1982). There is however, little information on the value of the whole plant (forage and root) as a meal for ruminant animals in Nigeria. 
In tropical America, a feeding system for ruminants based on the use of crop residues and whole crop biomass has been developed for the smallholder farmer (Ruiz, 1982). A similar system based on the whole crop of sweet potato may also be developed for feeding ruminant stock in Nigeria during the dry season. The use of sweet potato forage and root as a ruminant feed is expected to yield a better economic return in terms of land use efficiency and animal production.

This study reports the intake, weight gain, feed conversion ratio, digestibility and nitrogen balance of West African dwarf sheep fed different combinations of sweet potato forage and root in the total diet.

\section{Materials and Methods}

This study was conducted in two parts. The first part corresponds to the growth trial where intake, growth rate and feed conversion ratio of the animals were measured. The second part corresponds to the metabolic trial where digestibility and nitrogen balance of the animais were measured.

\section{Feed Preparation}

The sweet potato forage and root used in this experiment were collected from a field at the University of Ibadan. Fresh forages and roots were chopped using a fabricated machine. The chopped materials were sun dried on polythene sheets for 5-6 days. The dried sweet potato forage and roots were ground into a meal using a hammer mill and mixed in the following proportions; $0: 100,25: 75,50: 50,75: 25$ and 100:0 (forage: root). Salt, vitamin-mineral premix and oyster shell meal were each added to the mixtures at the rate of 0.5 percent. The mixtures were pelleted and stored for the feeding trial. The ingredient composition of the experimental diets is shown in Table 1.

\section{Growth Trial}

Fifteen male West African dwarf lambs approximately six months old with mean weight $8.3 \pm 1.7 \mathrm{~kg}$ were housed in separate pens with feeding and watering troughs. The animals were divided into three groups according to their weights and randomly assigned to one of five diets, containing sweet potato forage and root in the proportions specified above. The animals were treated with Ivomectin and Gamatox to take care of internal and external parasites. Animals were also treated with antibiotics before the commencement of the trial. Feed was offered $a d$ libtum at $105 \%$ of previous day's intake once daily at 8.00 hours. Fresh water was offered free choice on a daily basis. The animals were offered the experimental diets for 150 days. Ten days were allowed for adaptation to the pens and diets while experimental measurements were taken in the last 140 days. Feed offered and feed refused were recorded for each animal daily while animal weights were taken on a weekly basis, using a spring balance. Average daily intake (ADI) and average daily gain (ADG) were calculated for each animal over the 140-day period. Feed conversion ratio was also calculated for each treatment from $\mathrm{ADI}$ and $\mathrm{ADG}$.

\section{Metabolic Trial}

At the end of the growth trial, slated wooden platforms adapted for faecal and urine collection was introduced into the animal pens. Experimental diets were offered ad-libitum on a daily basis for 14 days. Total faeces, urine and feed refused were collected and weighed in the last 7 days. Feed intake, feacal output and urinary output were determined. Ten per cent of faeces and urine collected were taken for analysis. Feed and faecal samples were dried at $65^{\circ} \mathrm{C}$ to constant weight, milled and kept in airtight containers while urine samples were kept in a deep freezer at $-5^{\circ} \mathrm{C}$ until required for analysis. Apparent 
Table 1. Ingredient composition of experimental diets.

\begin{tabular}{lccccc}
\hline & \multicolumn{5}{c}{ Diets (forage: root) } \\
\cline { 2 - 6 } Ingredient & $0: 100$ & $25: 75$ & $50: 50$ & $75: 25$ & $100: 0$ \\
\hline Sweet potato forage & 0.0 & 24.6 & 49.2 & 73.9 & 98.5 \\
Sweet potato root & 98.5 & 73.9 & 49.3 & 24.6 & 0.0 \\
Salt & 0.5 & 0.5 & 0.5 & 0.5 & 0.5 \\
Vitamin-mineral premix & 0.5 & 0.5 & 0.5 & 0.5 & 0.5 \\
Oyster shell & 0.5 & 0.5 & 0.5 & 0.5 & 0.5 \\
Total & 100.0 & 100.0 & 100.0 & 100.0 & 100.0 \\
\hline
\end{tabular}

digestibility of the diets was calculated as the difference between nutrient intake and excretion in the faeces, expressed as a percentage of nutrient intake using the following equation:

$$
D_{X}=\frac{\left(F_{0} \times A_{\theta}\right)-\left(F_{1} \times A_{1}\right)}{\left(F_{0} \times A_{\theta}\right)} \times \frac{100}{1}
$$

Where $D_{x}=$ digestibility coefficient of nutrient

$$
\begin{aligned}
& F_{0}= \begin{array}{l}
\text { quantity of feed consumed in } \\
\text { grammes (DM) }
\end{array} \\
& A_{0}= \text { percent nutrient content in feed } \\
& \text { (DM) } \\
& F_{1}= \begin{array}{l}
\text { quantity of faeces voided in } \\
\text { grammes (DM) }
\end{array} \\
& A_{1}=\begin{array}{l}
\text { percent nutrient content in } \\
\text { faeces (DM) }
\end{array}
\end{aligned}
$$

Nitrogen retained by the animals was calculated as the difference between nitrogen intake and nitrogen excreted as follows:

$$
\mathrm{N}_{\text {retained }}=\mathrm{N}_{\text {intake }}-(\text { Faecal } \mathrm{N}+\text { Urinary } \mathrm{N})
$$

In this trial, the $100 \%$ sweet potato root $(0: 100)$ diet was sprayed with a $10 \%$ urea solution to raise the crude protein content to $8.85 \%$. This was done to avoid the incidence of low DM intake experienced by animals on this diet during the growth trial.
Chemical Analysis and Experimental Design Nitrogen content of feed, faeces and urine were' determined by the Kjedlahl method (AOAC, 1995) while proximate composition, detergent ribre and gross energy content of the feed and faeces were determined by the methods of AOAC (1995), Van Soest and Robertson (1985) and Nehring and Haenlein (1973) respectively.

The experimental design adopted for both trials was the randomized complete block design. Data obtained were subjected to analysis of variance and significant means were separated by Duncan's multiple range tests using the SAS (1995) procedures.

\section{Results and Discussion}

The chemical composition of the experimental diets is given in Table 2. The energy level in the diets are similar while crude protein and fibre components of the diets increased with increasing level of sweet potato forage in the diets. This is explained by the higher levels of protein and fibre in sweet potato forage compared to the root.

The dry matter intake, growth rate and feed conversion ratio of sheep fed the various 
Table 2. Chemical composition $(\mathrm{g} / 100 \mathrm{~g} \mathrm{DM})$ and energy $(\mathrm{kcal} / \mathrm{g})$ of sweet potato based diets

\begin{tabular}{lrrrrr}
\hline Components & $0: 100^{\circ}$ & $25: 75$ & $50: 50$ & $75: 25$ & $100: 0$ \\
\hline Dry matter & 93.80 & 93.20 & 92.60 & 92.40 & 91.60 \\
Crude protein & 4.85 & 9.05 & 12.65 & 16.28 & 20.05 \\
Ether extract & 1.15 & 1.86 & 2.55 & 3.15 & 3.85 \\
Crude fibre & 3.26 & 8.38 & 12.25 & 15.87 & 19.65 \\
Ash & 4.06 & 5.54 & 7.15 & 8.85 & 10.24 \\
Nitrogen free extract & 86.68 & 75.17 & 65.40 & 55.85 & 46.21 \\
Neutral detergent fibre & 9.24 & 18.25 & 28.20 & 36.05 & 45.06 \\
Acid detergent fibre & 4.00 & 10.35 & 16.45 & 22.50 & 28.00 \\
Lignin & 0.38 & 0.82 & 2.25 & 3.74 & 4.20 \\
Gross energy & 4.09 & 4.15 & 4.21 & 4.27 & 4.23 \\
\hline
\end{tabular}

* During the metabolic trial this diet was sprayed with a $10 \%$ urea solution to increase the nitrogen content hence the composition was altered as follows; DM: 92.65, CP: 8.85, EE: 1.14, CF: 3.25, Ash: 4.00, NFE: 82.76. NDF: 9.24 . ADF: 4.00 , Lignin: $0.35 \mathrm{~g} / 100 \mathrm{~g} \mathrm{DM}$; GE: $4.10 \mathrm{kcal} / \mathrm{g}$. This was done to avoid the incidence of low DM intake experienced by animals on this diet during the growth trial.

Table 3. Dry matter intake, growth rate and feed conversion ratio of WAD sheep fed sweet potato forage and root

\begin{tabular}{lcccccc}
\hline & \multicolumn{7}{c}{ Diets (forage: root ratio) } & & & \\
\cline { 2 - 7 } Parameter & $0: 100$ & $25: 75$ & $50: 50$ & $75: 25$ & $100: 0$ & SEM \\
\hline No. of animals & 3.00 & 3.00 & 3.00 & 3.00 & 3.00 & - \\
Initial weight, kg & 8.43 & 8.17 & 8.37 & 8.20 & 8.30 & 0.25 \\
Final weight, kg & 7.46 & 18.10 & 20.50 & 19.13 & 16.30 & 0.83 \\
& & & & & & \\
ADG, g/day & $-34.13^{\mathrm{e}}$ & $70.95^{\mathrm{c}}$ & $86.43^{\mathrm{a}}$ & $78.10^{\mathrm{b}}$ & $56.91^{\mathrm{d}}$ & 2.71 \\
& & & & & \\
ADI, g/day & $83.60^{\mathrm{d}}$ & $626.44^{\mathrm{b}}$ & $657.73^{\mathrm{a}}$ & $627.32^{\mathrm{b}}$ & $595.82^{\mathrm{c}}$ & 7.51 \\
ADI, \% BW & $1.80^{\mathrm{b}}$ & $4.81^{\mathrm{a}}$ & $4.67^{\mathrm{a}}$ & $4.57^{\mathrm{a}}$ & $4.98^{\mathrm{a}}$ & 0.28 \\
ADI, g/kg & $26.28^{\mathrm{b}}$ & $91.45^{\mathrm{a}}$ & $90.50^{\mathrm{a}}$ & $87.98^{\mathrm{a}}$ & $92.66^{\mathrm{a}}$ & 3.56 \\
FCR & $-2.44^{\mathrm{d}}$ & $8.84^{\mathrm{b}}$ & $7.62^{\mathrm{c}}$ & $8.03^{\mathrm{c}}$ & $10.48^{\mathrm{a}}$ & 0.30 \\
\hline
\end{tabular}

$. \mathrm{b}, \mathrm{c}, \mathrm{d}$ : Means with same superscript within the row are not significantly different $(\mathrm{P}>0.05)$

ADI: average daily intake, DM

ADG: average daily gain

FCR: feed conversion ratio (intake/gain)

BW: body weight

$\mathrm{W}^{0.75}$ : metabolic weight 
mixtures of sweet potato forage and roots are presented in Table 3.

\section{Dry Matter Intake}

Animals on the $100 \%$ sweet potato root $(0: 100)$ diet lost weight, scoured persistently and stopped eating by the 4 th week. This is thought to be due to the low level of protein $(4.9 \% \mathrm{CP})$ and fibre $(3.3 \% \mathrm{CF})$, which caused a digestive disorder in the rumen. The protein content of this diet ( $100 \%$ roots) is below the $6-7 \%$ minimum level recommended for ruminant diets by Milford and Haydock (1965).

There were significant differences $(P<0.05)$ in the dry matter intake from the diets on percent body weight or metabolic weight basis. This was due mainly to the low DM intake experienced by animals on $100 \%$ root diet. It is of note that DM intake from other diets was high and similar, suggesting that the nitrogen content of these diets were adequate for microbial activity in the rumen. The DM intake obtained in this study were $1.8,4.8,4.7,4.6$, and $4.9 \%$ of body weight (BW) for Diets I, II, III, IV and V respectively. These values were broadly higher than the range of $3.3-3.8 \% \mathrm{BW}$ obtained by Olorunnisomo and Ososanya (2002) for WAD goats fed maize offal and sorghum brewer's grains in a total diet. Backer et al. (1980) reported a mean DM intake of $2.37 \% \mathrm{BW}$ for cattle fed different mixtures of sweet potato forage and root. When expressed on metabolic weight basis, DM intake in this study were $26.3,91.5,90.5,88.0$, and $92.7 \mathrm{~g} / \mathrm{kg}$ $\mathrm{W}^{0.75}$ for the respective diets. These were higher than the mean DM intake of $43.6 \mathrm{~g} / \mathrm{kg} \mathrm{W}^{0.75}$ obtained by Olubajo and Aken'ova (1985) for sheep fed a sole diet of elephant grass, and $71 \mathrm{~g} /$ $\mathrm{kg} \mathrm{W}^{0.75}$ reported by Peyraud and Astigarraga (1998) for sheep fed different grass forages. The high DM intake observed in sweet potato based diets may have resulted from the high degradation rate in the rumen and consequently a faster rate of digesta passage through the gut. Growth Rate

The growth rate (average daily gain) of sheep differed significantly $(P<0.05)$ among the treatments. Animals fed equal proportions of sweet potato forage and root (50:50) showed the highest weight gain, followed by $75 \%$ forage (75:25), $25 \%$ forage (25:75) and $100 \%$ forage $(100: 0)$ respectively. Animals on $100 \%$ root $(0.100)$ had a negative weight change $(-34.13 \mathrm{~g} /$ day $)$. This might be a result of the low DM intake and digestive disorders induced by the low nitrogen concentration and low fibre content of the diet. High concentrate or low-fibre diets are known to cause feedlot bloat (excessive accumulation of gases in the rumen) in stall-fed ruminants (McDonald et al., 1987). Growth rate increased with increasing level of sweet potato forage in the diet up to $50 \%$ and then declined. The mean growth rates in this study were $-34.13,70.9,86.4$, 78.1 , and $56.9 \mathrm{~g} /$ day for $0: 100,25: 75,50: 50,75: 25$ and 100:0 respectively. These values are generally higher than the $44.2-63.5 \mathrm{~g} /$ day obtained by Lam and Ledin (2004) for goats fed sweet potato vines and Sesbania grandiflora forage, and the $11.9-67.9 \mathrm{~g} /$ day obtained by Adeneye and Sunmonu (1994) for WAD sheep fed grass-legume forage with concentrates.

\section{Feed Conversion Ratio}

The feed conversion ratio of WAD sheep fed the different diets is given in Table 3. There were significant differences $(\mathrm{P}<0.05)$ among the treatments in feed conversion ratio. When the diet consisted of sweet potato forage (100:0) or root $(0: 100)$ alone, FCR was high or negative, showing that feed was not efficiently converted by the animals. However, when the forage and root were mixed in the diet, FCR was lower, indicating a more efficient feed conversion. Animals on the 50:50 diets showed the best feed 


\section{Performance of WAD sheep fed sweet potato forage and roots}

conversion followed by $75: 25$ and $25: 75$ respectively. This is largely a reflection of the weight gain by the animals from the various diets. The feed conversion ratio for animals on $100 \%$ root diet was negative due to the negative weight change experienced by these animals. The difference between the feed conversion ratio of diets 50:50 and 75:25 was not significant $(P>0.05)$, showing that the conversion efficiency of these diets were similar. The feed conversion ratio obtained in this study were $-2.44,8.84,7.62,8.03$, 10.48 for sheep fed $0: 100,25: 75,50: 50,75: 25$ and 100:0 combinations of sweet potato forage and roots respectively. Apart from the 0:100 diet, mixtures of sweet potato forage and roots appear to be better converted to meat by small ruminants than elephant grass supplemented with cassava peels and palm kernel cake (Fasae et al., 2007) or pigeon pea-based diets (Arigbede et al., 2005). Abubakar et al. (2005) however reported a superior feed conversion ratio $(5.38$ - 7.35$)$ for goats fed complete diets based on groundnut haulms and cowpea shell.

\section{Digestibility}

The apparent digestibility of the various dietary combinations is given in Table 4. Results show there were significant differences $(\mathrm{P}<0.05)$ in $\mathrm{DM}$, $\mathrm{CP}, \mathrm{NDF}$ and ADF digestibility of the diets. The diet with $100 \%$ sweet potato root $(0: 100)$ had the least DM and CP digestibility while the 50:50 diet had the highest. Dry matter digestibility tended to improve with the inclusion of sweet potato forage in the diet. When sweet potato forage and root were mixed together in the diet, proteinenergy ratio and fibre content of the diet increased. This was probably responsible for the observed improvement in DM digestibility when sweet potato forage formed part of the diet. Digestion in ruminant animals is highly influenced by the level of protein and fibre in the diet. A low protein concentration in the diet reduces microbial synthesis and consequently, intake and digestibility of the diet is reduced (Olorunnisomo et al., 2006; McDonald et al., 1987). The quantity and nature of dietary fibre also influences microbial synthesis in the rumen. A good fibre mat must be maintained in the rumen to ensure adequate growth and activity of rumen microbes (Ishler et al., 1996). Diets with very low fibre contents can result in digestive disorders such as scours and feedlot bloat in ruminants. At equal proportions of sweet potato forage and root in the diet, protein-energy ratio was probably at the optimum level, thus providing an optimal condition for microbial synthesis in the rumen and DM digestibility of the diet.

The NDF and ADF followed a similar trend with DM digestibility with the $100 \%$ sweet potato root diet having the least values and diets containing sweet potato forage, higher values. Digestibility of fibre tended to improve with increasing levels of sweet potato forage in the diets. This is a reflection of the higher protein level in sweet potato forage relative to the root. This result agrees with other reports that increased level of protein in ruminant diets improved the digestibility of such diets (Olorunnisomo et al., 2006; Olorunnisomo and Ososanya, 2002; Peyraud and Astigarraga, 1998; McDonald et al., 1987; Ffoulkes et al., 1978).

\section{Nitrogen balance}

The utilization of nitrogen in the diets by WAD sheep is presented in Table 5. Results show that nitrogen intake from the diets and nitrogen loss in faeces increased with increasing level of sweet potato forage in the diets. This was a refection of the higher protein level in the forage compared to the root. Increased nitrogen loss in faeces is associated with higher protein intake by animals and higher protein concentration in the diet (Tolera and Sundstol, 2000; Chowdhury, 1997; 
Olorunnisomo

Table 4. Apparent digestibility (\%) of sun dried sweet potato forage and root by WAD sheep

Diets (forage: root ratios)

\begin{tabular}{|c|c|c|c|c|c|c|}
\hline Components (\%) & $0: 100$ & $25: 75$ & $50: 50$ & $75: 25$ & $100: 0$ & SEM \\
\hline Feed intake (g/day, DM) & 555.97 & 631.67 & 673.73 & 638.35 & 591.91 & 7.85 \\
\hline Faecal output (g/day, DM) & 196.86 & 209.76 & 199.65 & 203.20 & 190.96 & 5.03 \\
\hline Dry matter & $64.60^{b}$ & $66.79^{\mathrm{ab}}$ & $70.42^{a}$ & $68.25^{\mathrm{a}}$ & $67.78^{2}$ & 4.90 \\
\hline Crude protein & $55.76^{\mathrm{b}}$ & $60.19^{a b}$ & $65.74^{\mathrm{a}}$ & $64.34^{\mathrm{a}}$ & $64.72^{3}$ & 2.32 \\
\hline Neutral detergent fibre & $50.35^{b}$ & $52.68^{b}$ & $63.28^{3}$ & $60.53^{\mathrm{a}}$ & $64.24^{a}$ & 2.45 \\
\hline Acid detergent fibre & $40.35^{c}$ & $49.23^{b}$ & $59.35^{\mathrm{a}}$ & $57.52^{\mathrm{a}}$ & $59.72^{\mathrm{a}}$ & 2.81 \\
\hline
\end{tabular}

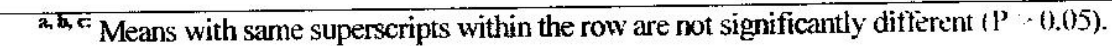

Table 5. Nitrogen balance of WAD sheep fed sun dried sweet potato forage and root

\begin{tabular}{|c|c|c|c|c|c|c|}
\hline \multirow[b]{2}{*}{ Measurement (g/day) } & \multicolumn{6}{|c|}{ Diets (forage: root ratios) } \\
\hline & $0: 100$ & $25: 75$ & $50: 50$ & $75: 25$ & $100: 0$ & SEM \\
\hline \multicolumn{7}{|c|}{50101} \\
\hline Feed intake (DM) & 555.97 & 631.67 & 673.73 & 638.35 & 591.91 & 7.85 \\
\hline$\% \mathrm{~N}$ in feed & 1.41 & 1.45 & 2.02 & 2.60 & 3.21 & - \\
\hline Faecal output (DM) & 196.86 & 209.76 & 199.65 & 203.20 & 190.96 & 5.03 \\
\hline$\% \mathrm{~N}$ in faeces & 1.77 & 1.74 & 2.34 & 2.93 & 3.51 & - \\
\hline Urinary output & 160.00 & 193.81 & 190.48 & 193.81 & 193.81 & 4.97 \\
\hline$\% \mathrm{~N}$ in urine & 1.30 & 1.12 & 1.05 & 1.19 & 1.54 & - \\
\hline $\mathrm{N}$ intake & 7.87 & 9.15 & 13.64 & 16.63 & 18.99 & 0.56 \\
\hline Faecal N & 3.48 & 3.64 & 4.68 & 5.94 & 6.70 & 0.29 \\
\hline Urinary $\mathrm{N}$ & 2.07 & 2.17 & 1.99 & 2.29 & 2.98 & 0.09 \\
\hline$N$ retained & 2.32 & 334 & 6.96 & 8.40 & 9.31 & 0.30 \\
\hline$\% \mathrm{~N}$ absorbed & $55.77^{\mathrm{b}}$ & $601,164^{417}$ & $65.74^{\mathrm{a}}$ & $64.39^{a}$ & $64.75^{\mathrm{a}}$ & 2.05 \\
\hline$\% \mathrm{~N}$ retained & $29.48^{\mathrm{b}}$ & $\therefore 50$ & $51.03^{\mathrm{a}}$ & $50.51^{\mathrm{a}}$ & $49.03^{a}$ & 1.78 \\
\hline
\end{tabular}

a. b: Means with same superscripts within the rom and not significantly different $(P>0.05)$

Bonsi et al. 1994). Nitrogen loss in the urine however did not follow a clearly defined pattern, with the 50:50 diets showing the least urinary $\mathrm{N}$ loss and the 100:0 diets, the highest. Total nitrogen retained increased with increasing levels of sweet potato forage in the diets. When expressed as a percentage of $\mathrm{N}$ intake, $\mathrm{N}$ retained differed significantly $(\mathrm{P}<0.05)$ among the diets. Animals on the 50:50 diets had the highest $\mathrm{N}$ retention while animals on $0: 100$ diets had the least. Nitrogen utilization by WAD sheep improved significantly $(\mathrm{P}<0.05)$ when sweet potato forage formed part or all of the diet. There was an improvement of 24 and $73 \%$ in N utilization when the forage formed 25 and $50 \%$ of the diet respectively; however, beyond the $50 \%$ inclusion level, there was no significant difference $(\mathrm{P}>0.05)$ in $\mathrm{N}$ retention among the experimental animals. 
This suggests that protein was better utilized when sweet potato forage and root were mixed in equal proportions in sheep diets.

Results from this study is consistent with the findings of Tolera and Sundstol (2000) and Bonsi et al. (1994) who reported an increase in $\mathrm{N}$ intake, faecal output and $\mathrm{N}$ retention with increasing level of protein in the total diet. The $\mathrm{N}$ retained as a percentage of $\mathrm{N}$ intake by sheep ranged from $29.5-51.0 \%$ in this study. These values were lower than the $55.5-60.8 \%$ nitrogen retention obtained by Tewe et al (1982) for lambs fed grass and concentrate diets but slightly higher than the $24.5-47.4 \%$ obtained by Adeneye and Sunmonu (1994) for sheep fed grass-legume forage with concentrates. Nitrogen absorbed followed a similar trend with $\mathrm{N}$ retention.

\section{Conclusion}

The intake, growth rate and feed conversion ratio of growing West African dwarf sheep improved when sweet potato forage and root were mixed in the diet. Digestibility and nitrogen utilization also improved with mixtures of the forage and root in the diet. Animal performance, digestibility and nitrogen utilization was highest when sweet potato forage and root formed equal proportions (50:50) in the diet. This suggests that optimum protein-energy ratio for microbial synthesis was achieved at this dietary combination of the forage and root. When the whole crop forms the basis for feeding ruminants, an equal proportion of the forage and root is recommended in the diet.

\section{References}

Abubakar M.,Adegbola T.A. and Abubakar M.M. 2005. Effects of varying levels of groundnut haulms and cowpea shell on the performance of weaner Red Sokoto goats. Nigerian Journal of Animal Production 32(2): 274-279.

Adeneye J.A. and Sunmonu E.M. 1994. Growth of male WAD sheep fed cassava waste or dried sorghum brewer's grain as supplements to tropical grass/legume forage. Small Ruminant Research 13:243-249.

An L.V., Frankow-Lindberg B.E. and Lindberg J.E. 2003. Effect of harvesting interval and defoliation on yield and chemical composition of leaves, stems and tubers of sweet potato (Ipomoea batatas (L) Lam.) cultivars. Field Crops Research 82(1): 49-58.

AOAC, 1995. Official Methods of Analysis. 16th Ed. Association of Official Analytical Chemists, Washington, DC.

Arigbede O.M., Olatunji J.E.N., Phillips O.B. and Shofunde K. 2005 . Performance of West African dwarf sheep fed pigeon pea (Cajanus cajan) based diets. Proceedings $10^{\text {th }}$ Annual Conference Animal Science Association of Nigeria. 12-15 September 2005, Ado-Ekiti. pp 197 200 .

Backer J., Ruiz M.E., Munoz H. and Pinchinat A.M. 1980. The use of sweet potato (Ipomoea batatas (L) Lam) in animal feeding. II. Beef production. Tropical Animal Production. 5(2): $152-160$

Bonsi M.L.K., Osuji P.O., Nsahlai I.V. and Tua A.K. 1994. Graded levels of Sesbania sesban and Leuceana leucocephala as supplements to Ethiopian Menz sheep. Animal Production 59:235-244.

Chowdhury S.A. 1997. Effect of low levels of leuceana foliage supplementation on intake, nutrient digestibility and microbial $\mathrm{N}$ yield in 
cattle fed rice straw alone. Asian-Australasian J. Anim. Sci. 10(3): 265-273.

Fasae O.A., Adegoke H.B., Ogunmekan K.O. and Adu I.F. 2007. Improving the feed utilization of cassava peels in smallholder goat production. Nigerian Journal of Animal Production. 34(2):251-257.

Ffoulkes D., DeB Hovell F.D. and Preston T.R. 1978. Sweet potato forage as cattle feed: voluntary intake and digestibility of mixtures of sweet potato forage and sugar cane. Trop. Anim. Prod 3(2): 140-144.

Giang H.H., Ly L.V. and Ogle B. 2004. Digestibility of dried and ensiled sweet potato roots and vines and their effect on the performance and economic efficiency of $\mathrm{F} 1 \mathrm{cross}$ bred fattening pigs. Livestock Research for Rural Development 16(7) www.cipav.org.co//rrd//rrd16/ 7/gian $16050 \mathrm{htm}$

Ishler V., Henrichs J. and Varga G. 1996. From feed to milk: understanding rumen function. Extension Circular 422. Pennsylvania State University, $27 \mathrm{pp}$.

Lam V. and Ledin I. 2004. Effect of feeding different proportions of sweet potato vines (Ipomoea batatas (L) Lam) and Sesbania grandiflora foliage in the diet on feed intake and growth of goats. Livestock Research for Rural Development $6(10)$.

McDonald P., Edwards R.A. and Greenhalgh J.F.D. 1987. Animal Nutrition. 5th Edition, Longman Scientific and Technical, Longman Group, UK Ltd.
Milford R. and Haydock K.P.H. 1965. The nutritive value of protein in subtropical pasture species grown in south-east Queensland. Aust. J. Exp.Agric. Anim. Husb.5: 13-17.

Moat M. and Dryden G.M. 1993. Nutritive value of sweet potato forage (Ipomoea batatas (L) Lam.) as a ruminant animal feed. Papua-New Guinea J. Agric. For. Fish. 36(1): 79-85.

Nehring K. and Haenlein G.F.W. 1973. Feed evaluation and ration calculation based on net energy (fat). J. Anim. Sci. 36:949.

Olorunnisomo O.A. and Ososanya T.O. 2002. Feed intake, digestibility and nitrogen balance of West African dwarf goats fed maize offal and sorghum brewer's grains. Tropical Animal Production Investigation 5:211-218.

Olorunnisomo O.A., Adewumi M.K. and Babayemi O.J. 2006. Effects of nitrogen level on the utilization of maize offal and sorghum brewer's grain in sheep diets. Livestock Research for Rural Development $18(01)$

www.cipav.org.co/lrrd//rrd18/01/ olor18010.htm

Olubajo F.O. and Aken'ova M.E. 1985. The voluntary intake and digestibility by sheep of Pennisetum purpureum (Schum) and of three interspecific $\mathrm{F}_{1}$ hybrid genotypes. Nig. J. Anim. Prod. 12(1): 79-87.

Peyraud J.L. and Astigarraga L. 1998. Review of the effect of nitrogen fertilization on the chemical composition, intake, digestion and nutritive value of fresh herbage: consequences on animal nutrition and $\mathrm{N}$ balance. Anim. Feed Sci. Tech. 72: 235-259. 
Rashid M.H., Bhuiyan M.K.R. and Ahmed M.S. 2000. Sweet potato breeding strategy in Bangladesh. African Potato Association Conf. Proc. Vol. 5. Pp59-60.

Ruiz M.E. 1982. Sweet potatoes (Ipomoea batatas (L) Lam) for beef production: Agronomic and conservation aspects and animal responses.

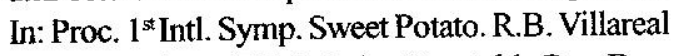
and T.D. Griggs (Eds.). Asian Vegetable Res. Dev. Center, Shanshua, Taiwan .pp 439-451.

SAS Institute, 1995. SAS/STAT User's Guide. Version $6,4^{\text {th }}$ Ed. Vol. 1 and 2 . SAS Inst. Inc., Cary, N.C.

Tewe O.O., Akinsoyinu A.O., and Ogissi E.M. 1982. Grain replacement value of cassava and sweet potatoes in rations for growing lambs.2. Energy and protein utilization. Nig. J. Anim. Prod. 9(2): 94-101.
Tolera A. and Sundstol F. 2000. Supplementation of graded levels of Desmodium intortum hay to sheep feeding on maize stover harvested at three stages of maturity 2 . Rumen fermentation and nitrogen metabolism. Anim. Feed Sci. Tech. 87:215-229.

Van Soest P.J. and Robertson J.B. 1985. Analysis of forages and fibrous foods. AS 613 Manual. Department of Animal Science, Cornell University, Ithaca, pp 105-106.

(Received 27th Feb. 2007; Accepted 15th Jan.. 2008) 